\title{
Příležitosti k rozvíjení interkulturní komunikační kompetence $v$ kontextu řečových dovedností: IVŠV videostudie anglického jazyka
}

\author{
Jana Zerzováa, Simona Šebestováb \\ a Masarykova univerzita, Pedagogická fakulta, Katedra anglického jazyka a literatury

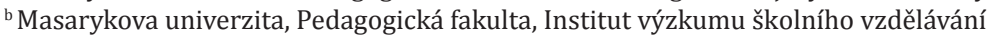

Redakci zasláno 8. 8. 2013 / upravená verze obdržena 28. 5. 2014 /

k uveřejnění přijato 10.6 .2014

\begin{abstract}
Abstrakt: Empirická studie je věnována problematice rozvíjení interkulturní komunikační kompetence (IKK) a její integraci s rozvíjením řečových dovedností ve výuce anglického jazyka (AJ) na 2 . stupni ZŠ. V rámci hledání odpovědi na otázku, jakým způsobem a za jakých podmínek rozvíjení IKK ve výuce AJ probíhá, je cílem této studie nahlédnout do toho, $v$ integraci s jakými řečovými dovednostmi je IKK rozvíjena a jaké je jejich zastoupení. Po úvodní části a vymezení teoretických východisek následuje část metodologická (kapitola 3) představující zkoumaný soubor (79 vyučovacích hodin AJ v 7. a 8. ročnících natočených u 25 učitelů na 2. stupni ZŠ ve třech krajích v rámci IVŠV videostudie anglického jazyka), způsob zpracování dat (způsob natáčení, transkripce, kódování), výzkumné otázky a kategoriální systémy (kategoriální systém IKK a kategoriální systém Řečové dovednosti), jež byly pro analýzu videozáznamů použity. Výsledky výzkumu naznačují, že mezi zastoupením řečových dovedností ve výuce a rozvíjením IKK existuje vztah, jenž se ve vzorku natočených hodin projevil vyšším zastoupením receptivních řečových dovedností a omezeným zastoupením produktivních řečových dovedností, vedoucím k rozvíjení IKK, jež se omezilo pouze na kognitivní úroveň, bez zastoupení zbývajících složek (konativní/behaviorální, afektivní).
\end{abstract}

Klíčová slova: výuka anglického jazyka, výuka cizího jazyka, IKK, interkulturní kompetence, interkulturní komunikační kompetence, komunikační kompetence, příležitosti k učení, řečové dovednosti, videostudie, vyučování a učení

Studie je věnována problematice rozvíjení interkulturní komunikační kompetence (IKK) ve výuce cizího jazyka (CJ). Pro realitu života v 21. století je osvojování IKK, jejímž vnějším projevem je schopnost efektivní komunikace např́ćc kulturami sociálně a kulturně citlivým způsobem, nezbytné. Bez systematického rozvíjení IKK na individuální i korporátní úrovni se může snadno naplnit předpověd' Samuela Huntingtona (1996) o tom, že konflik- 
ty a násilí v novém miléniu nebudou již primárně vycházet z ekonomických a ideologických kořenů, ale spíše z propasti vytvořené kulturními rozdíly.

Cizojazyčná výuka pak nabízí specifické možnosti pro rozvoj IKK žáků a studentů CJ a ačkoliv tato skutečnost není v současných kurikulárních dokumentech dle našeho názoru dostatečně reflektována (více viz Zerzová, 2012), je v nich naopak jasně vyjádřena potřeba získávání znalostí o jiných kulturách, rozvíjení dovedností a postojů žáků ve vztahu k vlastní kultuře i k jiným kulturám a jejich vzájemné interakci.

Předkládaná studie si proto klade za cíl prohloubit poznatky o tom, jak je realizováno rozvíjení IKK z hlediska příležitostí k uplatnění řečových dovedností v rámci výuky anglického jazyka (AJ). Zahrnuje-li IKK dvě složky - interkulturní a komunikační, pak propojením těchto dvou složek získáme komplexnější pohled na realizaci rozvíjení IKK ve výuce. Studie přináší odpověd' na otázku, zda výuka nabízí příležitosti k rozvíjení komunikační složky IKK, a pokud ano, jaké řečové dovednosti jsou ve výuce uplatňovány a zda s sebou tato zjištění přinášejí nějaké důsledky pro rozvíjení IKK žáků. ${ }^{1}$

\section{Teoretická východiska a vymezení pojmů}

\subsection{Př́ležitosti $k$ učení}

Cílem IVŠV videostudie anglického jazyka bylo provést explorativní analýzy procesů vyučování a dokumentovat, popsat a analyzovat proces výuky AJ na základních školách.

Celý projekt IVŠV videostudie anglického jazyka vychází v rovině teoretických východisek z konceptu př́ležitostí k učení (opportunities to learn, Lerngelegenheiten), který byl navržen jako teoretické východisko pro zkoumání procesu výuky v její komplexnosti (McDonnell, 1995). Př́ležitosti k učení umožňují usuzovat na potenciál výuky z hlediska podpory učení žáků. Tento potenciál lze zkoumat z různých hledisek: (a) př́ležitosti k učení nabízené

Studie vychází ze dvou nezávisle zpracovaných výzkumných šetření na témž výzkumném souboru. Stejný metodologický postup obou provedených analýz nabízí propojení jejich zjištění s cílem prohloubit poznatky o tom, jak je realizováno rozvíjení IKK (tomuto tématu bylo věnováno první šetření - srov. Zerzová, 2012), a to z hlediska příležitostí k uplatnění řečových dovedností (jimiž se zabývalo druhé šetření - srov. Šebestová, 2011). Obě již publikovaná výzkumná šetření (Zerzová, 2012; Šebestová, 2011) a jejich propojení formou této studie představují výstupy z projektu IVŠV videostudie anglického jazyka, jež probíhá od roku 2007 v Institutu výzkumu školního vzdělávání (IVŠV) Pedagogické fakulty Masarykovy univerzity v Brně (PdF MU). 
výukou a (b) př́ležitosti $\mathrm{k}$ učení využité žáky. $\mathrm{Z}$ hlediska metodologického př́istupu jsou při zkoumání př́ležitostí k učení uplatněny př́ístupy: (a) kvantitativní: př́ležitost k učení jako množství času (Carroll, 1963); (b) kvalitativní: to, co se žáci naučí, je závislé na kvalitě toho, co je jim výukou předkládáno (Doyle, 1983; Hiebert \& Wearne, 1993).

Jak uvádí Najvar et al. (2011, s. 90), „ve školní výuce by mělo jít především o vytváření př́ležitostí, ve kterých by žáci nejen zvládali určité učivo, ale byli schopni toto učivo instrumentalizovat v určitém situačním kontextu“. Př́ležitosti k učení pak nejsou chápány jen jako potenciál, který do výuky přináší učitel, ale výuka jako proces interakce mezi učitelem a žáky a žáky navzájem vytváří potenciál pro spoluvytváření příležitostí $\mathrm{k}$ učení. $\mathrm{V}$ předkládaném výzkumu se soustředíme na pozorovatelnou činnost žáků ve výuce, v níž je rozvíjena interkulturní komunikační kompetence (jako cílová kategorie cizojazyčného vzdělávání).

\subsection{Interkulturní komunikační kompetence ${ }^{2}$}

Termín kompetence je v rámci zde prezentovaného výzkumu vnímán jako holistický (srov. např. Píšová, 2005). Je také vnímán jako pojem komplexní, mající zastř̌ešující funkci, sestávající z dovedností, vědomostí, schopností a zahrnující postojovou a hodnotovou orientaci jedince (srov. Kubeš et al., 2004; Maňák, 2007; Skalková, 2007 a další).

Termín interkulturní komunikační kompetence dle Byrama (1997) je pak ve studii upřednostňován před termíny jinými ve snaze vystihnout komplexnost tohoto jevu a naznačit jeho souvislost s výukou CJ. Cílem rozvíjení IKK je aktivní používání cílového jazyka, sekundárně případně i mateřského jazyka v interkulturní interakci kulturně a sociálně citlivým způsobem, ne pouhé rozvíjení interkulturní kompetence v mateřském jazyce. Žádoucím cílem je, aby rozvíjení IKK probíhalo primárně v cílovém jazyce (srov. Fantini, 2006).

Analýzu modelů IKK za účelem didaktizace tohoto konstruktu v kontextu hodnocení rozvoje IKK publikovala Kostková (2012), řada modelů byla představena také v publikaci Zerzové (2012) v rámci didaktizace tohoto kon-

2 V literatuře se setkáváme s termíny komunikativní [sic] i komunikační kompetence, v této studii je však dána přednost termínu komunikační, jelikož výraz komunikativní [sic] je v kontextu IKK považován bohemisty za nepřesný a zavádějící (srov. Hrdlička, 2005). Rovněž preferujeme (v souladu s dalšími českými autory - srov. Faltýn, 2005; Kostková, 2012; Pešková, 2012) termín interkulturní před termínem multikulturní, ačkoliv lze konstatovat, že současná pedagogika s těmito termíny zachází nesystematicky a že je v této oblasti velmi těžké najít jednotný pojmový aparát (více viz Zerzová, 2012, s. 12-17). 
struktu v kontextu výzkumu realizovaného kurikula a analýzy procesu rozvíjení IKK, založeného na pozorování výuky.

Pro účely tohoto výzkumného šetření a jemu předcházejících analýz (Zerzová, 2012) vycházíme ze dvou pojetí (interkulturní) komunikační kompetence, která byla uplatněna ve dvou výzkumech, jež propojuje předkládaná studie. Uplatněná pojetí se liší tím, že každé z nich poskytuje východisko pro zkoumání IKK na jiné úrovni obecnosti a s jiným zaměřením³ ${ }^{3}$ První výzkumné šetření bylo zaměřeno na realizaci interkulturní složky IKK ve výuce, druhé se zaměřovalo na realizaci (cizojazyčné) komunikační složky IKK. Obě složky - komunikační i interkulturní - jsou navzájem provázané a v komunikaci se projevují současně, proto se nabízí propojení výstupů obou výzkumných šetření.

První výzkumné šetření se zaměřovalo na zkoumání interkulturní složky IKK. Za účelem jejího zkoumání vznikla potřeba vytvořit model, jenž by ilustroval didaktické dimenze IKK a tento komplexní pojem přiblí̌zil praxi výuky a výzkumu výuky. Vytvořený a uplatněný model vymezuje cílové oblasti rozvíjení IKK, ze kterých pak vychází kategoriální systém IKK (viz podkapitola 3.3.1) pro pozorování a analýzu výuky. Model je zasazen do kontextu výuky CJ a vyčleňuje složku interkulturní oproti složce komunikační, která je upozaděna, přestože striktně ji oddělit nelze. ${ }^{4}$ Při konstrukci tohoto modelu jsme vycházeli z již existujících modelů IKK, z nichž mnohé vymezují kognitivní, behaviorální a afektivní rovinu IKK a formulují konkrétní cíle pro tyto jednotlivé roviny ve formě znalostí, dovedností, postojů a hodnot (více viz Zerzová, 2012; Kostková, 2012), dále rozlišování kulturně obecných a kulturně specifických cílů (srov. Paige et al., 1999, cit. dle Göbel, 2007, s. 46; Bennett, Bennett, \& Allen 2003) a tzv. Big-C Culture a small-c culture ${ }^{5}$. Vzniklo tedy osm cílových oblastí rozvíjení IKK (viz obr. 1).

Teoretické konstrukty komunikační kompetence jsou spíše didakticko-lingvistické povahy, kdežto novější konstrukty interkulturní komunikační kompetence jsou více multidisciplinární.

4 Znalost cizího jazyka je vnímána jako důležitý faktor ovlivňující rozvoj IKK jedince (srov. Fantini, 2006). Dle našeho přesvědčení však nelze přijmout tvrzení, že výuka vedená v mateřském jazyce s cílem rozvoje některé dimenze IKK k rozvíjení její komunikační složky vůbec žádným způsobem nepřispívá. Výzkumy, které by se touto problematikou zabývaly, pochopitelně, vzhledem ke složitosti uchopení této problematiky, chybí.

5 Big-C Culture bývá rovněž označována jako Upper-Case Culture, achievement culture, Culture 1 nebo objective culture, zatímco small-c culture bývá označována jako lower-case culture, behavioral culture, Culture 2 nebo subjective culture (srov. Triandis, 1989; Stern, 1992; Tomalin \& Stempleski, 1993; Bennett, 1998; Bennett, Bennett, \& Allen, 2003; Hofstede \& Hofstede, 


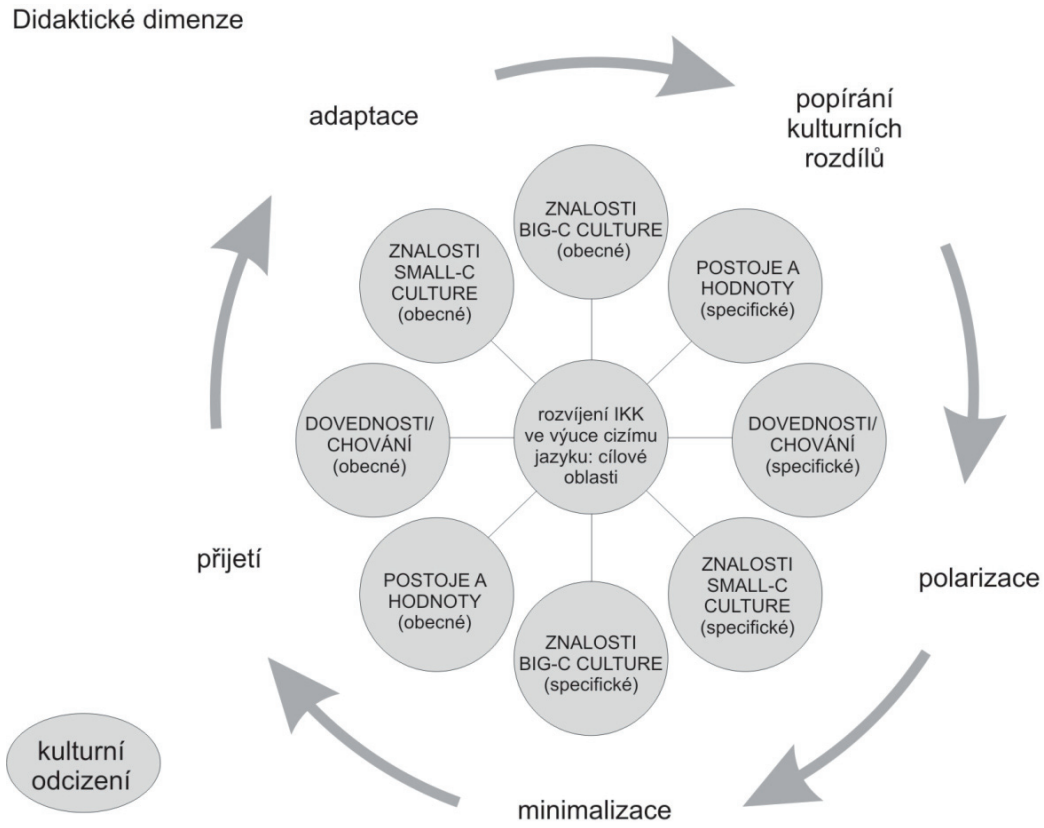

Obrázek 1. Model IKK ve výuce cizímu jazyku: didaktické dimenze (Zerzová, 2012, s. 56, upraveno).

Rozvíjení povědomí, jež je možno vnímat jako centrální oblast rozvíjení $\mathrm{IKK}^{6}$, není v tomto modelu vyčleněno jako samostatná cílová oblast, ale zůstává „skryto“ (zejména ve formě povědomí o vlastní kultuře a cizích kul-

2005). Big-C Culture zahrnuje především znalosti a poznatky z oblasti historie, zeměpisu, literatury, umění, institucí, politiky apod. Small-c culture dle Bennetta (1998) označuje psychologické rysy, které definují skupinu lidí - jejich každodenní smýšlení a jednání - spíše než instituce, které vytvořili. Nezahrnuje však jen znalosti o aspektech každodenního života jedinců dané kultury, ale rovněž rozvíjení široké škály dovedností a postojů, tedy afektivní a konativní/behaviorální součásti IKK. Ačkoliv jsou tyto dva termíny vždy uváděny v dichotomickém vztahu, je zřejmé, že se ve skutečnosti jedná o kontinuum, a že je tak učiněno pro zjednodušení a přiblížení těchto dvou konceptů.

6 K povědomív modelech IKK více viz Kostková (2012, s. 75-80) a navržený model interkulturní komunikační kompetence (Kostková, 2012, s. 74), obsahující čtyři základní dimenze: postoje, dovednosti, povědomí a znalosti, kde cizojazyčná komunikační kompetence tvoří další, pátou, zásadní dimenzi ICC, ve které jsou ostatní čtyři dimenze zakotveny. 
turách) v pěti vývojových fázích interkulturní kompetence znázorněných v modelu šipkami (popírání kulturních rozdílů, polarizace, minimalizace, príietí a adaptace), na které je možno se ve výuce zaměřit a kombinovat je se všemi osmi cílovými oblastmi. Tyto vývojové fáze vycházejí z Bennettova (1986) Vývojového modelu interkulturní kompetence (IK)/ interkulturní senzitivity (Developmental Intercultural Competence Model/ Developmental Model of Intercultural Sensitivity: DMIS) a na něj navazujícího Inventáře vývoje interkulturní kompetence: verze 3 (Intercultural Development Inventory: $I D I, v$. 3), který vypracoval Hammer (2009) v návaznosti na DMIS (Bennett, 1986). Jedná se o model (srov. Bennett, 1986; Hammer, 2009), který vnímá IK holisticky, soustřed'uje se na vymezení jednotlivých vývojových fází IK a vnímá jedince jako pohybujícího se po vývojovém kontinuu interkulturní kompetence z etnocentrických fází (popírání kulturních rozdílů, polarizace) přes minimalizaci až po etnorelativní fáze (přijetí, adaptace). ${ }^{7}$

Navržený kategoriální systém a následný výzkum se - vzhledem k designu výzkumu (pozorování videozáznamů výuky, hodiny AJ natočené jako celek) - ovšem nesoustředil na analýzu výuky z hlediska zaměření na ty to vývojové fáze, nýbrž pouze na vytváření př́ležitostí k učení z hlediska osmi navržených cílových oblastí. Ve výzkumu tak byla využita pouze část didaktizovaného modelu. Využití Vývojového kontinua interkulturní kompetence a Inventáře vývoje interkulturní kompetence (Intercultural Development Inventory: IDI) pro vzdělávací a výzkumné účely v České republice zůstává námětem pro vědecko-výzkumné projekty $\mathrm{v}$ budoucnosti a rovněž námětem $\mathrm{k}$ diskusi o vhodnosti použití tohoto inventáře. Rovněž není vyloučeno, že navržený didaktizovaný model IKK bude nutno v budoucích výzkumech $\mathrm{s}$ jiným designem revidovat.

Jestliže jsme výše představili IKK jako konstrukt komplexní, zahrnující kognitivní, behaviorální a afektivní rovinu s důrazem na interkulturní složku, nyní představíme blíže složku komunikační, jež zastupuje znalost cizího jazyka, a to s vědomím jistého zjednodušení, nebot' obě složky jsou vzájemně propojené a nelze je striktně oddělit.

Druhé výzkumné šetření se zaměřovalo na komunikační složku IKK. V oblasti cizojazyčného vzdělávání je pro dimenze cizojazyčné komunikace, jejichž zvládnutí vede k úspěšné komunikaci v cizím jazyce, (vedle pojmu interkul-

7 Ke stručnému popisu těchto vývojových fází a oddělené dimenze kulturního odcizení (cultural disengagement) více viz Zerzová (2012, s. 66). 
turní komunikační kompetence) užíván pojem komunikační kompetence. Celý koncept komunikační kompetence byl rozpracován $\mathrm{v}$ duchu rozlišování mezi znalostí jazykových prostředků (gramatiky, slovní zásoby, výslovnosti, pravopisu) a dovedností užívat jazyk v komunikaci. Pro účely operacionalizace konstruktu komunikační kompetence jsou vymezovány její dimenze, které zastupují dílčí kompetence (např. Bachman, 1990; Canale \& Swain, 1980; Savignon, 1983; Usó-Juan \& Martínez-Flor, 2006). Pojetí uvedených autorů zahrnovala dimenzi/kompetenci diskurzivní, lingvistickou, pragmatickou, interkulturní a strategickou, jež jsou realizovány v komunikaci řečovými dovednostmi. Jednotlivá pojetí se liší ve struktuře a vztazích mezi jednotlivými dimenzemi, nikoli zásadně v obsahovém vymezení.

Jednotlivé dimenze komunikační kompetence od sebe nelze oddělit, a nejsou tak přístupné př́imému pozorování. Posuzování komunikační kompetence spočívá v posuzování jejích projevů v řečové činnosti, a to prostřednictvím realizace čtyř řečových dovedností poslechu, mluvení, čtení a psaní (Šebestová, 2011).

V předkládané studii je komunikační složka nadřazeného konstruktu IKK reprezentována právě řečovými dovednostmi poslechem, mluvením, čtením a psaním jakožto konceptem vztahujícím se ke čtyřem druhům řečové činnosti, jež se podílí na procesu a efektivitě komunikace. Tyto mohou být děleny jednak podle druhu komunikačního procesu na receptivní a produktivní, jednak podle formy na mluvené a psané. $\mathrm{V}$ cizojazyčné výuce jsou řečové dovednosti jednak cílem, jednak prostředkem k dosahování komunikačního cíle.

Zde prezentované výzkumné šetření nahlíží výuku anglického jazyka z hlediska potenciálu, který žákům nabízí v oblasti rozvíjení IKK, a to z hlediska př́ležitostí k uplatňování řečových dovedností žáky. Řečové dovednosti jsou $\mathrm{v}$ této analýze prostředkem $\mathrm{k}$ realizaci cíle v podobě rozvíjení IKK.

Řečové dovednosti tvoří jádro komunikační kompetence, její výkonovou složku, prostřednictvím níž jsou všechny komponenty komunikační kompetence realizovány. Jak uvádí Šebestová (2011), ve výuce nejsou jednotlivé řečové dovednosti zastoupeny pouze separovaně, jedna po druhé, ale i v různých kombinacích. V této souvislosti se hovoří o integrovaném přístupu, jenž přesněji vystihuje povahu komunikace ve výukové praxi (Hinkel, 2006; Kumaravadivelu, 2001; Selinker \& Tomlin, 1986).

Ve výuce se proto jeví jako žádoucí, aby učitel předkládal žákům takové učební aktivity, v kterých žáci uplatňují více řečových dovedností současně. 
Učební aktivity integrující více řečových dovedností jsou komplexnější v tom, že žáci uplatňují různé druhy komunikačního procesu současně - recepci a produkci. (Šebestová, Najvar, \& Janík, 2011, s. 328)

Učební aktivity, které zahrnují řečovou recepci i produkci, vyžadují od žáka mluvenou či psanou reakci na psaný text či promluvu v cílovém jazyce. Častěji jsou proto zaměřeny více na význam než na formu, a disponují tak potenciálem $\mathrm{k}$ nácviku funkčního využívání cílového jazyka, nikoli pouze k manipulaci s jazykovým materiálem.

Výuka anglického jazyka v České republice vykazuje některé charakteristiky, jež nebývají př́liš diskutovány v anglosaské didaktice cizího jazyka. Jedná se o využívání mateřského jazyka v cizojazyčné výuce jednak jako jazyka vyučovacího, jednak ve formě překladu. Někteří autoři (Atkinson, 1987; Harbord, 1992; Swan, 1990) poukazují na to, že využívání mateřského jazyka v cizojazyčné výuce $\mathrm{v}$ omezené míre může být pro výuku přínosné, je-li mateřský jazyk užíván smysluplně, tedy v prŕípadech, kdy se jeho využití jeví jako efektivnější (např. úspornější z hlediska času, umožňující přesnější vyjádření, pro zdůraznění rozdílů mezi jazyky). Na druhé straně se obecně poukazuje na výhody užívání cílového jazyka co nejvíce i jako jazyka vyučovacího tak, aby byl vytěžen jeho co největší potenciál (Šebestová, 2011).

Výzkumy, které by se zabývaly efektivitou rozvíjení IKK v mateřském a cílovém jazyce chybí. Rozvíjení IKK by však mělo probíhat převážně v cílovém jazyce proto, aby byla cíleně rozvíjena i komunikační složka IKK (Byram, 1997; Fantini, 2006 a další).

\subsection{Výzkumy kvality výuky interkulturní komunikační kompetence.}

Počet dosud realizovaných výzkumů výuky v oblasti rozvíjení IKK je rovněž omezený. Výsledky dřívějších analýz (Zerzová, 2012), na které tato studie navazuje, ukázaly, že se učitelé účastnící se tohoto výzkumu ${ }^{8}$ ve výuce zaměřovali převážně na kognitivní složku IKK a rozvíjení znalostí žáků a věnovali velmi málo pozornosti rozvíjení jejich dovedností, postojů a hodnot. Tato zjištění odpovídají tradičnímu pojetí výuky reálií. Zdá se, že dovednosti potřebné v kontextu interkulturních interakcí jsou ve výuce rozvíjeny jen omezeně a s postoji žáků k cizím kulturám a interkulturním interakcím není pracováno systematicky.

8 Ke zkoumanému souboru více viz podkapitola 2.1. 
Pokud bychom tyto výsledky chtěli srovnat s výsledky jiných šetření, nacházíme se v nelehké situaci. Většina modelů a nástrojů vymezujících a testujících IKK byla navržena mimo kontext výuky CJ, což se samožrejmě odráží i ve výzkumu.

V kontextu vzdělávání byly ovšem rovněž provedeny rozsáhlé výzkumy (jak ve Spojených státech amerických, takv dvaceti pěti evropských zemích), které upozorňují na to, že vzdělávání budoucí učitele nepřipravuje dostatečně ani na jednání v interkulturních situacích, ani na výuku samotnou (Dunnett et al., 1986; Met, 1993; Kelly, 2002; Guilherme, 2002; Sockett \& LePage, 2002; Lázár, 2003). Výzkumy uskutečněné ve Spojených státech amerických, Belgii, Velké Británii a Dánsku rovněž ukazují, že učitelům chybí systematický plán pro rozvíjení IKK a jednání s předsudky žáků v hodinách výuky CJ, stejně jako kriteria, která by jim rozhodování usnadnila (Sercu, 2002b; Met, 1993). Důsledkem je, že se učitelé nacházejí v situaci, kdy mají naplňovat řadu vzdělávacích cílů, pro které se necítí dostatečně vybaveni (Byram \& Morgan, 1994; Sercu, 2002a).

Výsledky těchto výzkumných šetření pouze nepř́mo napovídají, jak by tato zjištění mohla být reflektována ve výuce, nenabízejí však možnost srovnání se zde prezentovaným výzkumným šetřením.

V rámci německé videostudie DESI (Deutsch Englisch Schülerleistungen International) byl realizován výzkum kvality interkulturní výuky anglického jazyka (Göbel, 2007). Do té doby nebyl v této oblasti rozsáhlejší empirický výzkum - nejen v Německu - realizován (srov. Göbel, 2007). Vzhledem k tomu, že design tohoto výzkumu byl odlišný od výzkumu provedeného v rámci IVŠV videostudie anglického jazyka (10 natočených hodin, zadaná témata, zadané některé konkrétní výukové materiály) v podstatě nemůžeme učinit žádná srovnání s výzkumem prezentovaných v této studii, ačkoliv se jedná o ojedinělý př́pad výzkumu kvality výuky IKK.

Jestliže je počet realizovaných zahraničních empirických výzkumů výuky v oblasti rozvíjení IKK v rámci výuky CJ omezený, tím více to platí o situaci v České republice, kde takový výzkum dosud nebyl uskutečněn. ${ }^{9}$

9 Řada zahraničních i domácích výzkumů v oblasti multikulturní výchovy zabývajících se problematikou postojů, předsudků a stereotypů, interkulturních rozdílů mezi etniky a pokusy o měření národní a etnické identity byla popsána v publikacích Průchy $(2001,2006)$. Byly provedeny výzkumy interkulturních komunikačních procesů a hodnotové orientace studentů na Vysoké škole ekonomické v Praze v rámci výzkumného projektu CEMS (Bočánková, 2006). 
V letech 2008/2009 však provedla Česká školní inspekce (Souhrnné poznatky o podpoře a rozvoji výuky cizích jazyků $v$ predškolním, základním a středním vzdělávání v období let 2006-2009) šetření, ve kterém se soustředila mimo jiné i na zařazení multikulturní výchovy a práci s reáliemi zemí vyučovaného jazyka ve výuce. Šetření v roce 2008/2009, k němuž se vztahuje většina analyzovaných údajů a zjištění, bylo realizováno ve dvou etapách: v 1. pololetí školního roku 2008/2009 a od února 2009, kdy probíhalo tematické šetření s využitím dalších specifických evaluačních nástrojů. Počet hospitovaných hodin v rámci tohoto šetření byl 1378 na ZŠ a 671 na SŠ. Dle údajů České školní inspekce byla multikulturní výchova zařazena v 83 \% hodin a s reáliemi zemí vyučovaného jazyka se žáci seznamovali v $62 \%$ hodin. Tyto údaje jsou platné pro výuku CJ obecně, ne pouze výuku anglického jazyka a nerozlišují procentuální zastoupení zkoumaných jevů na ZŠ a SŠ. Zpráva rovněž neuvádí kriteria výskytu multikulturní výchovy v rámci hospitovaných hodin, čímž je hodnota prezentovaných zjištění značně limitována. Tyto výsledky se však odlišují od výsledků analýzy výuky provedené v rámci IVŠV videostudie anglického jazyka (více viz kapitola 4).

\section{Výzkumné šetření - metodologie}

\subsection{Metodologie - zkoumaný soubor a zpracování dat}

Způsob sběru dat v rámci IVŠV videostudie anglického jazyka byl popsán v dřívějších publikacích (srov. Najvar et al., 2008, 2011), proto se zde omezíme pouze na základní údaje o zkoumaném souboru. Projektu se zúčastnilo 25 učitelů $\left(n=23\right.$ žen +2 muži ${ }^{10} \mathrm{z}$ náhodně vybraných škol ze tří krajů (Jihomoravský, Olomoucký a Zlínský). Celkem bylo natočeno 79 vyučovacích hodin AJ v 7. a 8. ročnících na 2. stupni ZŠ.

Dále byl realizován výzkum interetnických vztahů v rámci projektu Varianty (Navrátil, 2002), z novějších výzkumů pak výzkum vztahu kognitivní a afektivní dimenze multikulturních kompetencí, který realizoval Hladík (2010). Na Univerzitě Pardubice proběhl výzkum IKK studentů učitelství AJ (Brebera \& Kostková, 2008), jehož cílem bylo odpovědět na otázku, zda u studentů učitelství AJ dochází během dílčí části studia k rozvoji IKK a pokud ano, v jakých doménách/kategoriích a k jakému rozvoji. Tomuto tématu je věnována monografie Rozvoj interkulturní komunikační kompetence (Kostková, 2012), stejně jako další již publikované příspěvky téže autorky (napřr. Kostková, 2010a, 2010b). Žádný z těchto výzkumů ovšem nepředstavuje empirický výzkum výuky IKK.

10 V celém příspěvku je jednotně používán výraz učitel pro všechny vyučující, kteří se do projektu zapojili, a to i v př́ípadě, že se jedná o ženy. 
Způsob natáčení probíhal standardizovaným způsobem (Janík \& Miková, 2006) dvěma videokamerami - žákovskou, která snímá aktivitu většiny žáků pohledem z rohu třídy od tabule a učitelskou, která snímá zejména aktivitu učitele.

K transkripci a kódování pořízených dat byl použit program Videograph (Rimmele, 2002), který byl vyvinut na IPN v německém Kielu. Program Videograph umožňuje kromě transkripce také kódování videozáznamu do předem definovaných kategoriálních systémů.

Transkripce probíhala podle standardizovaného postupu (Seidel et al., 2003; Janík \& Miková, 2006). Videozáznamy byly transkribovány zaznamenáváním výpovědí učitele (U), žáka (Z), několika žáků (ZZ) nebo celé třídy (T). Videozáznam byl transkribován $\mathrm{v}$ desetisekundových intervalech, včetně sekvencí, ve kterých byl použit audiozáznam (CD) nebo videozáznam (V).

\subsection{Metodologie - výzkumné otázky}

Hlavním cílem již publikovaného výzkumu rozvíjení IKK (srov. Zerzová, 2012) bylo sledování časové dimenze rozvíjení IKK, což odpovídá celkovému konceptu a teoretickému východisku pojetí vyučování jako vytváření př́ležitostí k učení.

Dále byl výzkum rozvíjení IKK konkretizován pomocí řady dílčích cílů a následné analýzy se zaměřovaly na obsahovou dimenzi výuky - tedy na kvalitu prríležitostí $k$ učení pro rozvoj IKK z hlediska zaměření na kognitivní, behaviorální/konativní a afektivní složku IKK, z hlediska zaměření na Big-C Culture a small-c culture a dále zaměření na specifická a obecná kulturní témata a obsahy. ${ }^{11}$

V rámci hledání odpovědi na otázku, jakým způsobem a za jakých podmínek rozvíjení IKK v rámci výuky AJ probíhá, je pak cílem této studie nahlédnout do toho, jaké řečové dovednosti jsou ve výuce IKK uplatňovány a jaké je jejich zastoupení. Př́ležitosti k rozvíjení IKK představují situace ve výuce propojující složky interkulturní (kategoriální systém IKK) a komunikační (kategoriální systém Řečové dovednosti).

11 Dalšími dílčími cíli výzkumu bylo zjistit, vjakém jazyce je IKK rozvíjena, vjakých organizačních formách a výukových fázích a jaké didaktické prostředky a média učitelé při výuce využívají. Těmto třem naposled jmenovaným dílčím cílům se však tato studie ani okrajově nevěnuje. K prvnímu zmiňovanému cíli (problematika používání cizího a mateřského jazyka ve výuce) je pak přistoupeno z jiného hlediska (více viz Zerzová, 2012; Šebestová, 2011). 
Z cíle výzkumu byly odvozeny následující výzkumné otázky:

Do jaké míry a jakým způsobem je rozvíjení IKK realizováno prostřednictvím rozvíjení řečových dovedností?

1 Do jaké míry a jakým způsobem je rozvíjení IKK realizováno prostřednictvím jednotlivých řečových dovedností?

2 Do jaké míry a jakým způsobem je rozvíjení IKK realizováno prostřednictvím integrace řečových dovedností?

3 Do jaké míry a jakým způsobem probíhá rozvíjení IKK v hodinách AJ v cílovém a mateřském jazyce?

\subsection{Metodologie - kategoriální systémy}

Pro účely již publikovaných analýz byly nezávisle na sobě sestaveny dva kategoriální systémy - kategoriální systém IKK a kategoriální systém Řečové dovednosti.

Kategoriální systém IKK sestává z deseti kategorií. Kategorie jsou rozděleny na kulturně obecné a kulturně specifické dle Paige et al. (1999, cit. dle Göbel, 2007, s. 46) a Bennett, Bennett a Allen (2003), přičemž se v obou těchto skupinách nacházejí čtyři paralelní kategorie zohledňující kognitivní, behaviorální/konativní a afektivní roviny IKK. V kategoriálním systému je rovněž využito rozlišování tzv. Big-C Culture a small-c culture.

Kategorie 1 a 5 (ZNALOSTI BIG-C CULTURE) zahrnují kognitivní rovinu IKK a odpovídají konceptu Big-C Culture. Kategorie 2, 3, 4, 6, 7 a 8 odpovídají small-c culture, přičemž kategorie 2 a 6 (ZNALOSTI SMALL-C CULTURE) zahrnují pouze kognitivní rovinu small-c culture. Kategorie 3 a 7 (DOVEDNOSTI/CHOVÁNÍ) zahrnují behaviorální/konativní dimenze IKK a kategorie 4 a 8 (POSTOJE/HODNOTY) reflektují rozvíjení afektivních úrovně IKK žáků. První kategorie 0 (žádná) označuje fázi před začátkem nebo po ukončení vyučovací hodiny. Poslední kategorie 9 označuje fázi vyučovací hodiny, která není pro rozvíjení interkulturní složky IKK rozhodující. Toto dělení je pro přehlednost znázorněno v tabulce 1 spolu se stručným vymezením jednotlivých kategorií. 


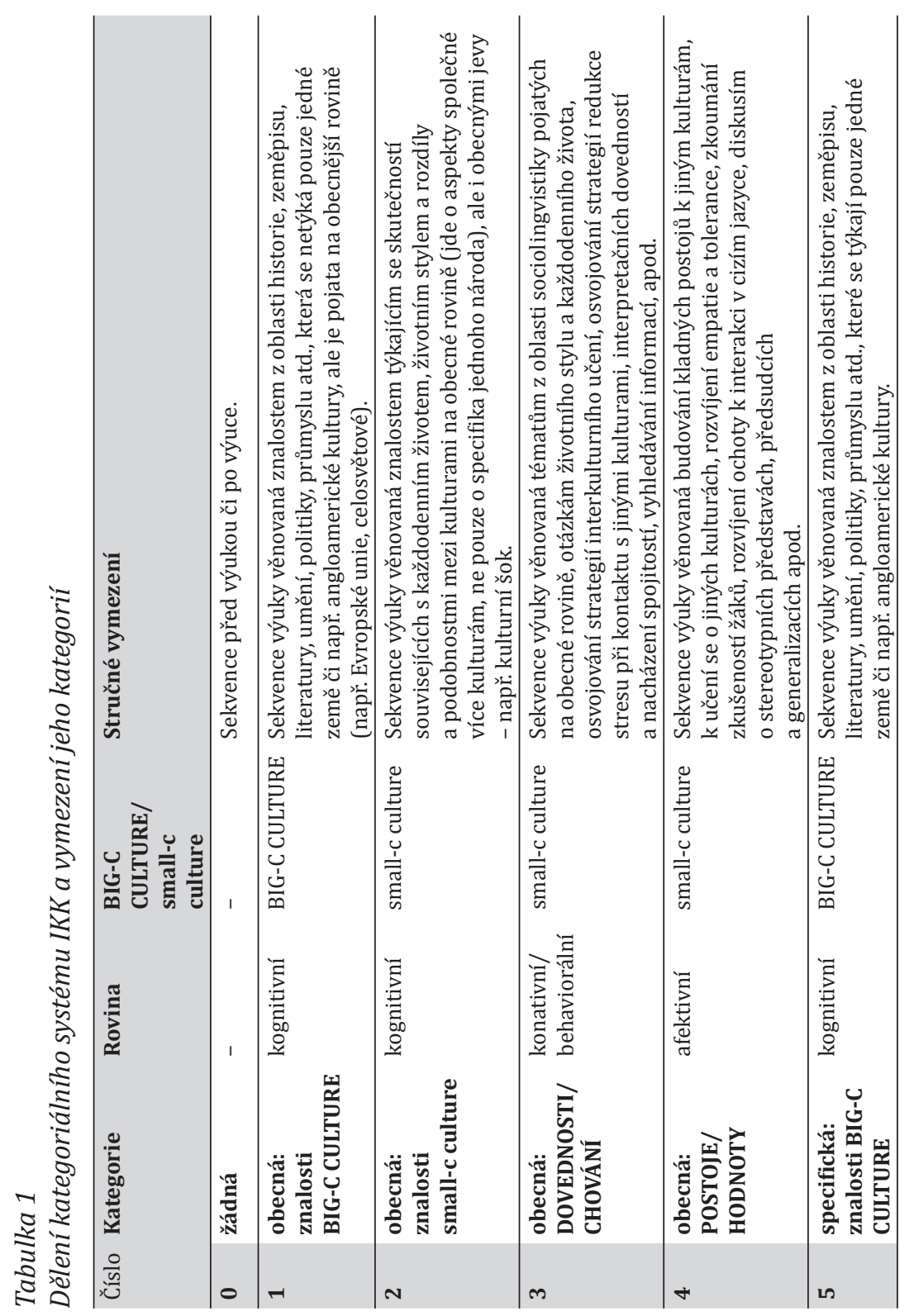




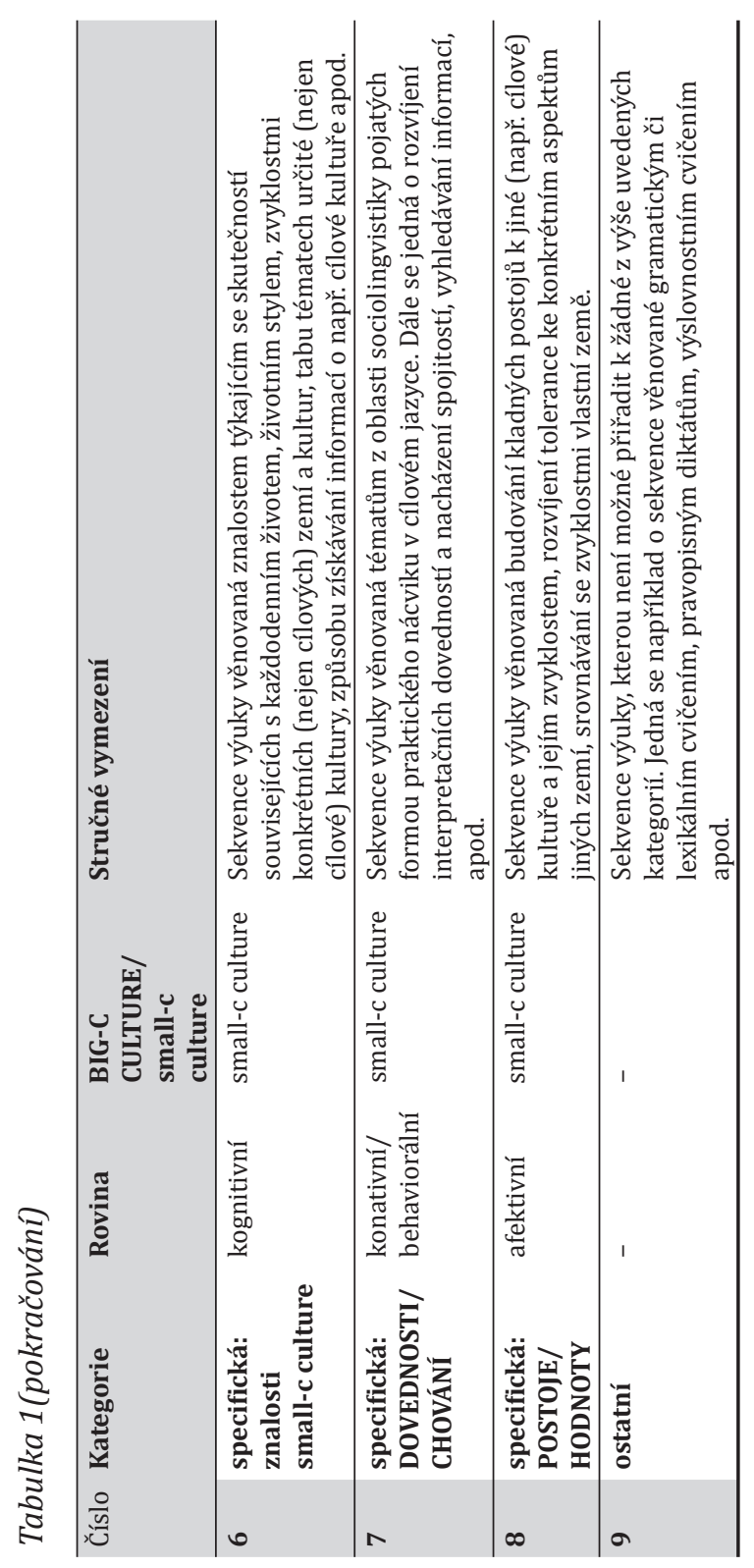




\section{Tabulka 2}

\section{Kategoriální systém Řečové dovednosti - vymezení kategorií}

\begin{tabular}{|c|c|c|}
\hline Číslo & Kategorie & Stručné vymezení a př́íklady aktivit \\
\hline $\mathbf{0}$ & Žádná & Sekvence před výukou či po výuce. \\
\hline 1 & Mluvení (S) & $\begin{array}{l}\text { Souvislá promluva žáka v cílovém jazyce. Utvoření věty } \\
\text { z jednoho údaje. }\end{array}$ \\
\hline 2 & Psaní (W) & Písemná výpověd' žáka v cílovém jazyce. Přepis (z tabule). \\
\hline 3 & Poslech (L) & $\begin{array}{l}\text { Poslech s porozuměním. Organizační pokyny učitele } \\
\text { v anglickém jazyce. }\end{array}$ \\
\hline 4 & Čtení (R) & $\begin{array}{l}\text { Čtení s porozuměním nebo se zaměřením na správnou } \\
\text { výslovnost. Překlad čteného do mateřského jazyka. }\end{array}$ \\
\hline 5 & Mluvení-poslech (SL) & $\begin{array}{l}\text { Integrace mluvení a poslechu. Učitel vede rozhovor se třídou } \\
\text { Žáci vedou rozhovor mezi sebou navzájem. }\end{array}$ \\
\hline 6 & Mluvení-čtení (SR) & $\begin{array}{l}\text { Integrace mluvení a čtení. Žáci odpovídají na napsané otázky } \\
\text { na otázky na základě čteného textu. Větné transformace. }\end{array}$ \\
\hline 7 & Mluvení-psaní (SW) & Integrace mluvení a psaní. \\
\hline 8 & Poslech-čtení (LR) & $\begin{array}{l}\text { Integrace poslechu a čtení. Žáci poslouchají a zároveň mají } \\
\text { plnit úkoly na základě čteného materiálu. }\end{array}$ \\
\hline 9 & Poslech-psaní (LW) & $\begin{array}{l}\text { Integrace poslechu a psaní. Diktát. Zápis jen některých částí/ } \\
\text { slov ze slyšeného. }\end{array}$ \\
\hline 10 & Čtení-psaní (RW) & $\begin{array}{l}\text { Integrace čtení a psaní. Žáci písemně odpovídají na napsané } \\
\text { otázky. Doplňují slova/věty/části vět do textu. Písemně } \\
\text { seřazují věty v odstavci; dokončují věty. }\end{array}$ \\
\hline 11 & $\begin{array}{l}\text { Mluvení-poslech- } \\
\text { čtení (SLR) }\end{array}$ & $\begin{array}{l}\text { Integrace mluvení, poslechu a čtení. Učitel klade otázky } \\
\text { a žáci na základě čteného textu odpovídají. }\end{array}$ \\
\hline 12 & $\begin{array}{l}\text { Mluvení-poslech- } \\
\text { psaní (SLW) }\end{array}$ & $\begin{array}{l}\text { Integrace mluvení, poslechu a psaní. Žáci si navzájem diktují } \\
\text { věty (napřs. běhací diktát). Žáci vedou rozhovor v anglickém } \\
\text { jazyce a zapisují si. }\end{array}$ \\
\hline 13 & $\begin{array}{l}\text { Poslech-čtení-psaní } \\
\text { (LRW) }\end{array}$ & $\begin{array}{l}\text { Integrace poslechu, čtení a psaní. Žáci během poslechu } \\
\text { pracují se čteným materiálem a písemně zpracovávají úkoly. }\end{array}$ \\
\hline 14 & $\begin{array}{l}\text { Mluvení-čtení-psaní } \\
\text { (SRW) }\end{array}$ & Integrace mluvení, čtení a psaní. \\
\hline 15 & $\begin{array}{l}\text { Mluvení-poslech- } \\
\text { čtení-psaní (SLRW) }\end{array}$ & $\begin{array}{l}\text { Integrace mluvení, poslechu, čtení a psaní. Tzv. information- } \\
\text { gap aktivity. Žáci čtou předem připravené otázky, odpovídají } \\
\text { na ně, píší si poznámky. }\end{array}$ \\
\hline 16 & Př̀eklad & Překlad z mateřského do cílového jazyka. \\
\hline 17 & $\begin{array}{l}\text { ČJ jako vyučovací } \\
\text { jazyk }\end{array}$ & $\begin{array}{l}\text { Výuka se týká anglického jazyka, ale probíhá v českém } \\
\text { jazyce. }\end{array}$ \\
\hline 18 & Ostatní & $\begin{array}{l}\text { Organizační pokyny. Netýkají se výuky angličtiny jako } \\
\text { takové, nýbrž její organizace. Probíhá v českém jazyce. }\end{array}$ \\
\hline
\end{tabular}


Kategoriální systém Řečové dovednosti - při jeho tvorbě byl uplatněn koncept řečových dovedností v jejich integrovaném pojetí (podrobněji viz Šebestová, 2011). Toto pojetí umožňuje kódovat pomocí kombinací řečových dovedností (např poslech-mluvení). Kódování tak umožňuje postihnout téměř veškerou komunikaci ve výuce, která probíhá v anglickém jazyce. Níže představujeme kategoriální systém (tabulka 2), ve kterém jsou zastoupeny kategorie reprezentující učební aktivity, v nichž žáci uplatňují jednu řečovou dovednost (kategorie 1-4), dvě řečové dovednosti (kategorie 5-10), tři řečové dovednosti (kategorie 11-14) a všechny čtyři řečové dovednosti (kategorie 15). Dále kategoriální systém zahrnuje situace, v nichž je uplatněn mateřský jazyk (kategorie 16-17) a dvě kategorie (0 a 18), které zastupují situace, jež se př́mo netýkají výuky.

\section{Vybrané výsledky}

Prvním a druhým dílčím cílem prvotního výzkumu rozvíjení IKK (srov. Zerzová, 2012) bylo zjistit, jaká je četnost a kvalita př́ležitostí k rozvoji IKK žáků v hodinách AJ. Ve výzkumu prezentovaném v této studii jsme se proto dále zaměřili na analýzu pouze těch sekvencí, ve kterých byla věnována pozornost rozvíjení některé složky IKK. Tyto sekvence pak představovaly $10 \%$ celkového vyučovacího času ${ }^{12}$, přičemž žádné $\mathrm{z}$ nich se nevyskytly v $62 \%$ zkoumaných vyučovacích hodin. Vzhledem $\mathrm{k}$ tomu, že výzkum rovněž ukázal silné zaměření na znalosti žáků, vyskytují se v níže uvedených grafech a tabulkách právě jen kategorie zaměřené na rozvíjení znalostí žáků. ${ }^{13}$

Cílem zde prezentovaného výzkumu pak bylo odpovědět na otázku, do jaké míry a jakým způsobem je rozvíjení IKK realizováno prostřednictvím uplatňování řečových dovedností.

3.1 Do jaké míry a jakým způsobem je rozvíjení IKK realizováno prostřednictvím řečové recepce a produkce?

Výsledky ukázaly (graf 1 , tabulka 3), že převážnou část rozvíjení IKK tvoří zaměření výuky na znalosti specifické - týkající se jedné země nebo kulturního prostředí. Žáci při tom nejčastěji uplatňovali čtení (58,83\%), poslech

336 minut 40 sekund.

13 Ve vzorku natočených hodin se ovšem vyskytlo několik problematických sekvencí, u nichž bylo učiněno konečné rozhodnutí ve prospěch kódování kategoriemi reprezentujícími kognitivní rovinu místo roviny afektivní a konativní/behaviorální (podrobněji viz Zerzová, 2012, s. 98). 
(36,35 \%), výrazně méně pak psaní $(24,20 \%)$ nebo mluvení $(13,06 \%)$. Část výuky probíhala v českém jazyce $(14,40 \%)$.

V nejvýrazněji zastoupené kategorii specifická - ZNALOSTI BIG-C CULTURE, která reprezentovala výuku věnovanou znalostem faktů týkajících se jedné země, uplatňovali žáci nejčastěji čtení, méně poslech a psaní, nepatrně mluvení. V druhé nejvýrazněji zastoupené kategorii specifická - ZNALOSTI SMALL-C CULTURE zahrnující výuku věnovanou znalostem týkajícím se každodenního života, zvyklostí a životního stylu rovněž dominovalo čtení, méně byl zastoupen poslech a nepatrně psaní a mluvení.

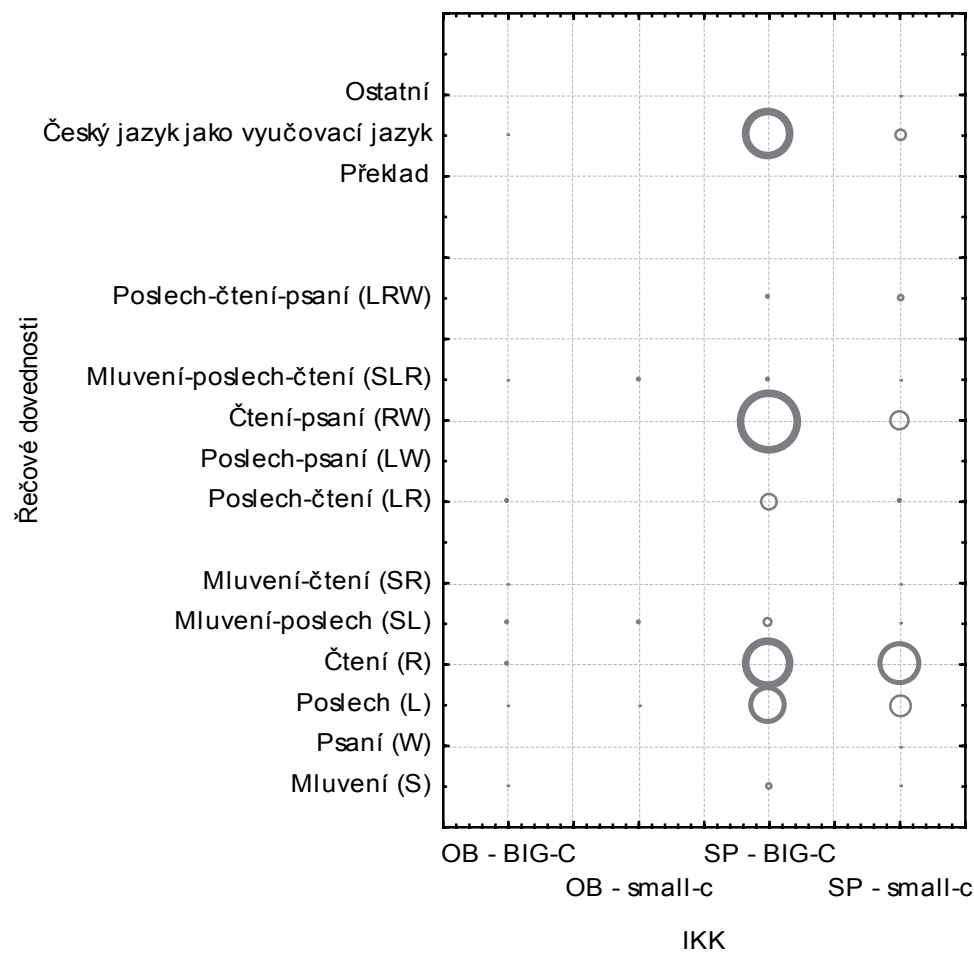

Graf 1. Vztahy mezi rozvíjením IKK a řečovými dovednostmi. 
Tabulka 3

Zastoupení jednotlivých řečových dovedností, českého jazyka a překladu při rozvíjení IKK

\begin{tabular}{|c|c|c|c|c|c|c|}
\hline & & \multicolumn{5}{|c|}{ Interkulturní komunikační kompetence } \\
\hline & & $\begin{array}{l}\text { obecná - } \\
\text { znalosti } \\
\text { BIG-C } \\
\text { Culture (\%) }\end{array}$ & $\begin{array}{l}\text { obecná - } \\
\text { znalosti } \\
\text { small-c } \\
\text { culture (\%) }\end{array}$ & $\begin{array}{l}\text { specifická - } \\
\text { znalosti } \\
\text { BIG-C } \\
\text { Culture (\%) }\end{array}$ & $\begin{array}{l}\text { specifická - } \\
\text { znalosti } \\
\text { small-c } \\
\text { culture (\%) }\end{array}$ & $\begin{array}{l}\text { Zastoupení } \\
\text { řečových } \\
\text { dovedností při } \\
\text { rozvíjení IKK } \\
\text { celkem }(\%)\end{array}$ \\
\hline \multirow{4}{*}{ 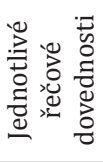 } & Mluvení & 2,13 & 2,13 & 6,58 & 2,22 & 13,06 \\
\hline & Psaní & 0,00 & 0,00 & 16,73 & 7,47 & 24,2 \\
\hline & Poslech & 3,9 & 2,53 & 19,39 & 10,53 & 36,35 \\
\hline & Čtení & 3,41 & 1,24 & 34,05 & 20,13 & 58,83 \\
\hline \multirow{3}{*}{ 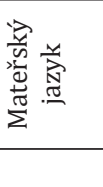 } & Překlad & 0,00 & 0,00 & 0,59 & 0,00 & 0,59 \\
\hline & $\begin{array}{l}\text { ČJ jako } \\
\text { vyučovací } \\
\text { jazyk }\end{array}$ & 0,15 & 0,00 & 11,23 & 3,02 & 14,4 \\
\hline & Ostatní & 0,00 & 0,00 & 0,49 & 0,45 & 0,94 \\
\hline
\end{tabular}

Příležitosti k rozvíjení IKK lze charakterizovat jako zaměřené na jednu zemi nebo kulturu (nejčastěji angloamerickou), výuka je zaměřena na znalosti faktů o životě, zvycích a tradicích $v$ této zemi nebo kultuře. $V$ obou př́ípadech uplatňovali žáci především receptivní řečové dovednosti, tzn. informace především přijímali čtením či poslechem. Relativně nízké zastoupení produktivních řečových dovedností při rozvíjení IKK ukazuje, že žáci verbálně reagovali v cílovém jazyce jen minimálně.

Chápeme-li v tomto příspěvku příležitost k učení jako výukovou situaci, v níž se střetává složka interkulturní a komunikační, pak nás zajímají ty situace, v nichž lze nalézt posuny směrem od porozumění jazykového k porozumění interkulturnímu. Proto zde předkládáme ukázky z výuky anglického jazyka $\mathrm{k}$ ilustraci, jak toto probíhá v reálné výuce. ${ }^{14}$

Tabulka 4 představuje př́klad části výuky věnované rozvíjení kognitivní složky IKK prostřednictvím poslechu a čtení. Jako kategorie IKK AJ 1: obecná: ZNALOSTI BIG-C CULTURE (6 minut 30 sekund) byla kódována část hodiny,

14 Studie si neklade za cíl uvádět pouze příklady dobré praxe. Uvedené ukázky reprezentují rozmanitost reálné výuky. 
ve které žáci používali učebnici ${ }^{15}$, ale pouze ty části, které se vztahovaly k zeměpisným údajům. Učitel pustil žákủm jednu položku poslechu, poté byli žáci jednotlivě vyvoláváni a měli danou položku přečíst. Takto přečetli všech 10 položek poslechu.

Tabulka 4

Ukázka transkriptu hodiny Aj_A1/2 - IKK AJ 1: obecná: ZNALOSTI BIG-C CULTURE - poslech-čtení

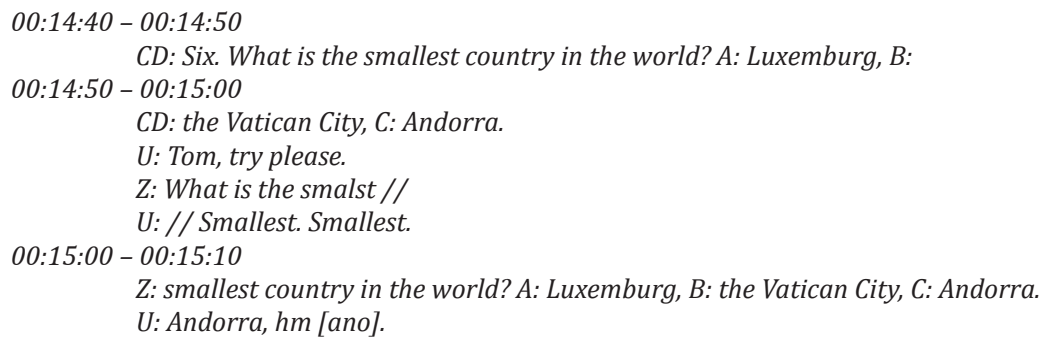

Uvedená ukázka ilustruje situaci, v níž žáci uplatňují především receptivní řečové dovednosti poslech a čtení. Žáci se vyjadřovali k tomu, která odpověd' je podle nich správná a druhou částí poslechu zkontrolovali, zda mají pravdu. V této fázi hodiny neprocvičovali tedy pouze 3. stupeň př́́davných jmen, ale rovněž se soustředili na pravdivost uvedených zeměpisných údajů, které se nevztahovaly pouze $\mathrm{k}$ jedné zemi či kultuře. Proto byla tato fáze výuky kódována jako IKK AJ 1 (obecná: ZNALOSTI BIG-C CULTURE).

Následující ukázka ilustruje výukovou situaci, v níž výuka probíhá formou rozhovoru učitele se třídou, žáci tedy mohou verbálně reagovat na otázky učitele. Během hodiny probíhalo ústní opakování základních údajů o Velké Británii a dále kladl učitel žákům krátké otázky o Skotsku. Zde byla tedy kódována kategorie IKK AJ 5 (specifická: ZNALOSTI BIG-C CULTURE).

15 Hutchinson, T. (1999). Project 2. Student's Book. Oxford: Oxford University Press. Ve výuce byla používána strana 54 . 
Tabulka 5

Ukázka transkriptu hodiny Aj_B1/1 - IKK AJ 5: specifická: ZNALOSTI BIG-C CULTURE - mluvení-poslech

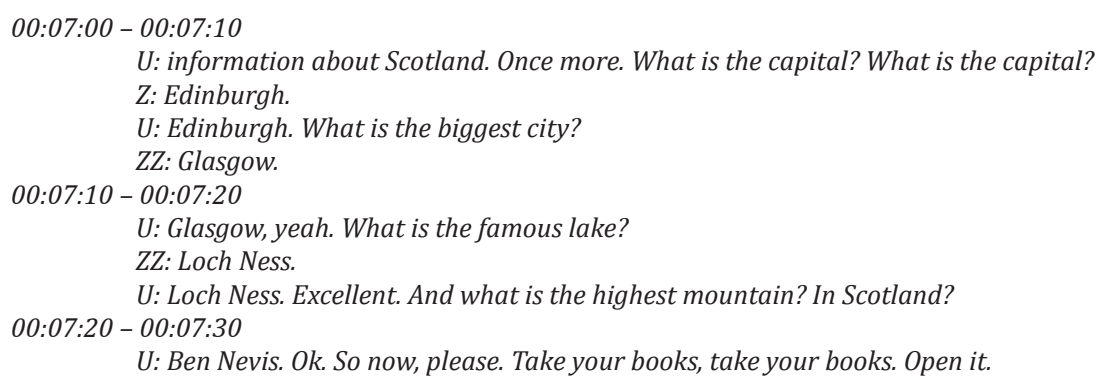

3.2 Do jaké míry a jakým způsobem je rozvíjení IKK realizováno prostřednictvím př́ležitostí $k$ integraci řečových dovedností?

Častěji byly řečové dovednosti uplatněny žáky samostatně než v integraci (viz tabulka 6). Z kategorií integrujících více řečových dovedností se nejčastěji vyskytovaly kategorie čtení-psaní $(19,64 \%)$, poslech-čtení $(7,77 \%)$ a mluvení-poslech $(5,44 \%)$. Kategorie integrující 3 a více řečových dovedností nebyly ve výuce výrazně zastoupeny. 
Tabulka 6

Zastoupení řečových dovedností v integraci, českého jazyka a prekekladu při rozvíjení IKK

\begin{tabular}{|c|c|c|c|c|c|c|}
\hline & & \multicolumn{5}{|c|}{ Interkulturní komunikační kompetence } \\
\hline & & $\begin{array}{l}\text { obecná - } \\
\text { znalosti } \\
\text { BIG-C } \\
\text { Culture } \\
(\%)\end{array}$ & $\begin{array}{l}\text { obecná - } \\
\text { znalosti } \\
\text { small-c } \\
\text { culture } \\
(\%)\end{array}$ & $\begin{array}{l}\text { specifická - } \\
\text { znalosti } \\
\text { BIG-C } \\
\text { Culture } \\
\text { (\%) }\end{array}$ & $\begin{array}{l}\text { specifická - } \\
\text { znalosti } \\
\text { small-c } \\
\text { culture } \\
(\%)\end{array}$ & $\begin{array}{l}\text { Všechny } \\
\text { Skupiny } \\
(\%)\end{array}$ \\
\hline \multirow{11}{*}{ 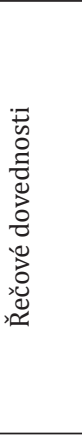 } & Mluvení & 0,25 & 0,00 & 1,78 & 0,10 & 2,13 \\
\hline & Psaní & 0,00 & 0,00 & 0,74 & 0,84 & 1,58 \\
\hline & Poslech & 0,84 & 0,25 & 9,15 & 5,79 & 16,03 \\
\hline & Čtení & 1,04 & 0,00 & 11,48 & 10,49 & 23,01 \\
\hline & Mluvení-poslech & 0,99 & 1,04 & 2,77 & 0,64 & 5,44 \\
\hline & Mluvení-čtení & 0,30 & 0,00 & 0,45 & 0,59 & 1,34 \\
\hline & Poslech-čtení & 1,48 & 0,15 & 4,60 & 1,53 & 7,76 \\
\hline & Poslech-psaní & 0,00 & 0,00 & 0,05 & 0,00 & 0,05 \\
\hline & Čtení-psaní & 0,00 & 0,00 & 14,70 & 4,95 & 19,65 \\
\hline & Mluvení-poslech-čtení & 0,59 & 1,09 & 1,58 & 0,89 & 4,15 \\
\hline & Poslech-čtení-psaní & 0,00 & 0,00 & 1,24 & 1,68 & 2,92 \\
\hline \multirow{4}{*}{ 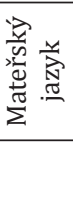 } & Překlad & 0,00 & 0,00 & 0,59 & 0,00 & 0,59 \\
\hline & ČJ jako vyučovací jazyk & 0,15 & 0,00 & 11,23 & 3,02 & 14,40 \\
\hline & Ostatní & 0,00 & 0,00 & 0,49 & 0,45 & 0,94 \\
\hline & Všechny skupiny & 5,64 & 2,53 & 60,85 & 30,97 & \\
\hline
\end{tabular}

Tabulka 7 představuje transkript velmi zajímavé části hodiny z hlediska rozvíjení IKK. Kódovány byly sekvence, ve kterých žáci pracovali ve skupinkách s pracovním listem. ${ }^{16}$ Měli za úkol diskutovat o zadaných otázkách na téma „Couch Potato Generation“. Učitel jednotlivé skupinky obcházel a pomáhal jim otázky zodpovědět. Sekvence v tabulce 7 obsahují potenciál pro kódování jako kategorie IKK AJ 3 obecná: DOVEDNOSTI/CHOVÁNÍ z toho důvodu, že žáci rozvíjí interpretační dovednosti a nacházení spojitostí a vztahují výraz „couch potato generation“ $\mathrm{k}$ různým národnostem. Jelikož učitel položil otázku pouze dvěma skupinkám, v ostatních skupinkách žáci diskutovali o jiných otázkách a v závěrečné fázi, kdy společně shrnovali odpovědi na otázky, tato otázka nezazněla, byly tyto sekvence kódovány jako IKK AJ 2 (obecná: ZNALOSTI SMALL-C CULTURE), protože se netýkaly všech žáků ve tř́́dě.

${ }_{16}$ Pracovní list $\mathrm{Aj}_{-} \mathrm{V} 1, \mathrm{v}$ databázi projektu. 


\section{Tabulka 7}

Ukázka transkriptu hodiny Aj_V1 - IKK AJ 2: obecná: ZNALOSTI SMALL-C CULTURE - mluvení-poslech-čtení

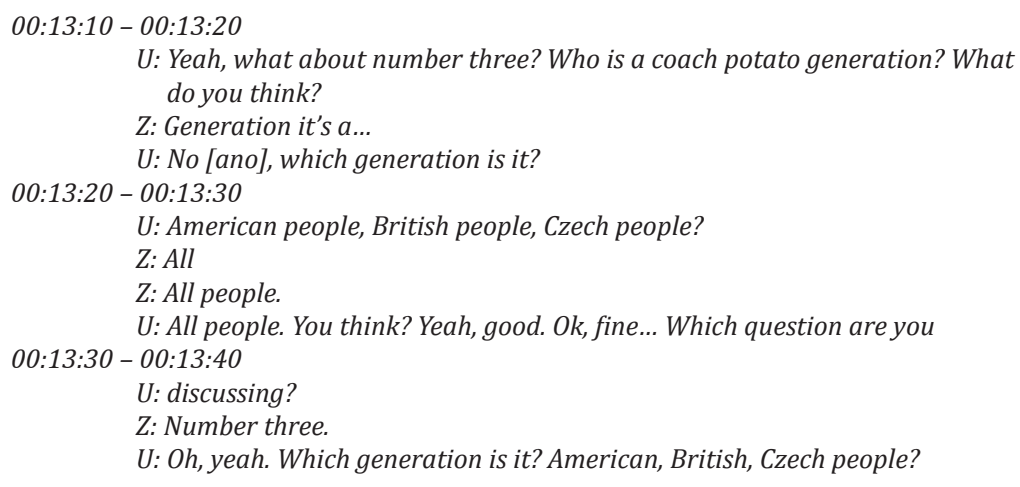

Z hlediska řečových dovedností uplatnili žáci tři řečové dovednosti - mluvení, poslech a čtení. Uvedená výuková aktivita žákům umožnila jazyk nejen přijímat čtením textu, ale také produkovat v reakci na text, otázky učitele i ve vzájemné diskusi, čímž se zvýšila náročnost zadané úlohy.

Uvedenou výukovou situaci lze charakterizovat jako příležitost k provázání jazykového porozumění, prostřednictvím něhož žáci poznávají různé národnosti ve vztahu k tématu coach potato generation. Potenciál situace je zvýšen také možností verbálně reagovat, a získat tak zpětnou vazbu na míru porozumění a vlastní interpretaci.

\subsection{Do jaké míry a jakým způsobem probíhá rozvíjení IKK v hodinách AJ $v$ cílovém a mateřském jazyce?}

Rozvíjení IKK probíhalo většinu času v anglickém jazyce, český jazyk byl zastoupen zhruba v $15 \%$ času ${ }^{17}$. Spadaly sem situace, které se týkaly sekvencí,

17 Jednalo se o situace týkající se výuky angličtiny, ale probíhající v českém jazyce. Z pohledu pozorovatele šlo zejména o ty sekvence výuky, v nichž učitel či žáci mluvili o angličtině česky, např. při vysvětlování gramatiky, slovní zásoby atd. Kódovaly se 10sekundové intervaly, v nichž probíhala verbální komunikace. Pokud probíhala komunikace v českém jazyce, spadaly situace do kategorie český jazyk jako jazyk vyučovací. Pokud probíhala komunikace v anglickém jazyce, spadaly situace do jedné z dovednostních kategorií (podrobněji ke kódování viz Šebestová, 2011, s. 119-122, 145-158). 
v nichž docházelo k rozvíjení IKK, ale učitel a/nebo žáci mluvili o daném tématu v mateřském jazyce (např. ukázka v tabulce 8).

Níže (tabulka 8,9) uvádíme dva př́íklady sekvencí, z nichž je patrné, že volba vyučovacího jazyka může být na úkor kvality výuky. Používání cílového jazyka ve výuce ve výše uvedených transkriptech (tabulky 4, 5 a 7) můžeme z tohoto hlediska naopak považovat za efektivní využití cílového jazyka v hodině (žáci rozumí, spolupracují, jsou rozvíjeny jejich řečové dovednosti, znalosti, vyvozují závěry).

V hodině, z níž uvádíme př́klad $v$ tabulce 8 , měli žáci za úkol pracovat s pracovním listem z předcházející hodiny $\left(\mathrm{Aj}_{-} \mathrm{C} 2\right)^{18}$ a ve dvojicích vytvořit vlastní podobný pracovní list na formát A3, kam psali upravený a zjednodušený text př́běhu o Kunta Kinte a malovali obrázky k příběhu. Tato fáze hodiny, kdy probíhala práce žáků ve dvojicích, byla kódována jako IKK AJ 5 (specifická: ZNALOSTI BIG-C CULTURE), jelikož se žáci soustředili na obsah textu, který pojednával o obsahu literárního díla (Roots).

Část hodiny, která byla kódována jako IKK AJ 6 (specifická: ZNALOSTI SMALL-C CULTURE) je uvedena $\mathrm{v}$ tabulce $8 \mathrm{~s}$ širším kontextem (včetně sekvencí 00:06:20 - 00:06:30 a 00:07:30 - 00:07:40). Celou tuto sekvenci iniciovala otázka žáka, kterou učitel využil $\mathrm{k}$ výkladu v mateřském jazyce. Bylo učiněno rozhodnutí kódovat tuto sekvenci jako specifické ZNALOSTI SMALL-C CULTURE z toho důvodu, že ačkoliv žák sám inicioval otázku, jednalo se následně pouze o výklad učitele a ve výsledku žáci nebyli vedeni $\mathrm{k}$ tomu, aby daný výraz použili. Navíc se jednalo o výraz specifický pouze pro určitou etnickou skupinu, a tudíž neaplikovatelný pro tuto situaci, věcná správnost výuky tedy byla narušena. Sekvence byly kódovány jako IKK AJ 6 (specifická: ZNALOSTI SMALL-C CULTURE), ačkoliv způsob výkladu narušoval kvalitu výuky. Žáci se dozvěděli, že není vhodné v angličtině používat slovo „black“, ale je vhodné je nahradit slovem „Afroameričan“.

18 Pracovní listy Aj_C2 v databázi projektu (Roots. Kunta Kinte’s Master). 


\section{Tabulka 8}

Ukázka transkriptu hodiny Aj_C3 - IKK AJ 6 (specifická: ZNALOSTI SMALL-C CULTURE) - český jazyk jako vyučovací jazyk

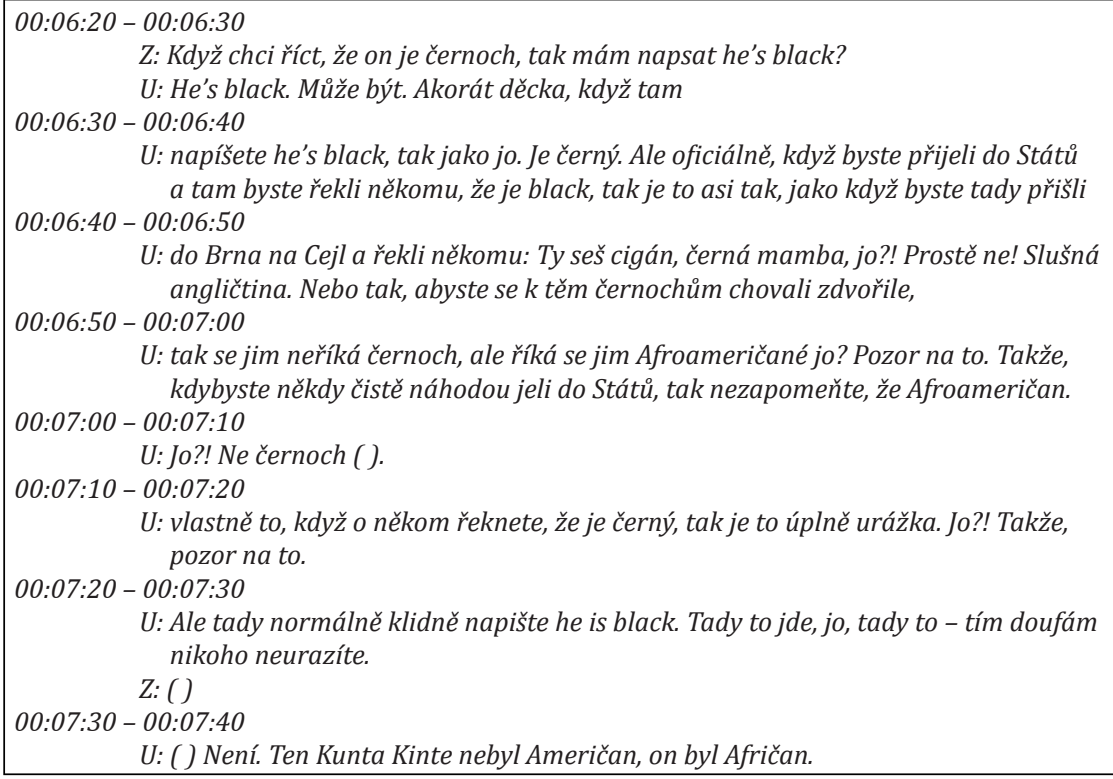

Rovněž použití anglického jazyka nebylo vždy zcela efektivní. Z tabulky 9 je patrné, že ačkoliv výuka probíhala v cílovém jazyce, tento nebyl žákům přizpůsoben natolik, aby rozuměli (comprehensible input).

Tabulka 9

Ukázka transkriptu hodiny Aj_S3 - IKK AJ 5 (specifická: ZNALOSTI BIG-C CULTURE) - poslech

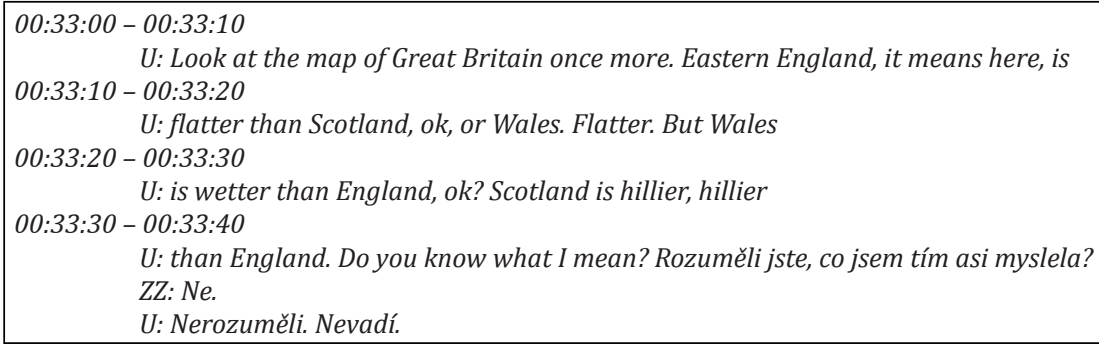




\section{Shrnutí výsledků, diskuse a závěry}

Výsledky dřivějších analýz (Zerzová, 2012), jak již bylo uvedeno výše, ukázaly, že se učitelé ve svých hodinách zaměřovali zejména na obsahy kulturně specifické, na úkor obsahů kulturně obecných a na Big-C Culture, případně znalosti z oblasti small-c culture, přičemž rozvíjení dovedností žáků, jejich hodnot a postojů zůstalo zanedbáno.

Ze závěrů výzkumu prezentovaného v této studii se pak nabízí domněnka, že uplatnění řečových dovedností hraje při rozvíjení všech složek IKK klíčovou roli. Zkoumané příležitosti k rozvíjení IKK vykazují znaky spíše jednostranného zaměření opomíjejícího behaviorální/konativní a afektivní dimenze IKK. Ve vzorku byly zastoupeny především receptivní řečové dovednosti (čtení a poslech), jejichž prostřednictvím je možno efektivně rozvíjet kognitivní složku IKK. V př́ípadech, ve kterých se produktivní řečové dovednosti ve výuce vyskytly, se jednalo opět o rozvíjení kognitivní složky IKK a zpravidla o reprodukci učiva. Je pravděpodobné, že vyšším zastoupením produktivních řečových dovedností (mluvení a psaní) by byly vytvořeny př́iznivější podmínky pro rozvíjení konativní/behaviorální a afektivní složky IKK. Z hlediska integrace řečových dovedností lze rozvíjení IKK charakterizovat vyrovnaným zastoupením řečových dovedností samostatně a v integraci. Receptivní řečové dovednosti se ve vzorku vyskytovaly často samostatně, naproti tomu pokud žáci měli př́ležitost k uplatnění produktivních řečových dovedností, jednalo se o učební aktivity integrující více řečových dovedností zahrnující oba druhy komunikačního procesu - recepci i produkci. Žáci tak měli př́ležitost verbálně reagovat na slyšenou promluvu či čtený text, jež byly však zpravidla využity k předávání kognitivních obsahů, jak již bylo uvedeno. Př́ležitosti k rozvíjení komunikační složky se při rozvíjení IKK ukázaly jako limitované, což má do jisté míry za následek i omezené příležitosti k rozvíjení její interkulturní složky.

Rozvíjení IKK probíhalo kromě anglického jazyka také v jazyce českém, a to především $v$ situacích zaměřených na faktografické znalosti jedné země. Zde se nabízí domněnka, že vyšší zastoupení anglického jazyka ve výuce by rovněž mohlo přinést více př́ležitostí k rozvíjení zejména dovedností žáků, protože řadu dovedností potřebných pro efektivní komunikaci je žádoucí rozvíjet přímo $\mathrm{v}$ cílovém jazyce. Jestliže je český jazyk využíván v případech zprostředkovávání kognitivních obsahů, není překvapující, že se využití cílového jazyka pro rozvíjení dovedností žáků stává př́iliš ambiciózním cílem. 


\section{Literatura}

Atkinson, D. (1987). The mother tongue in the classroom: A neglected resource? ELT Journal, 41(4), 241-247.

Bachman, L. (1990). Fundamental considerations in language testing. New York: Oxford University Press.

Bennett, M. J. (1986). A developmental approach to training for intercultural sensitivity. International Journal for Intercultural Relations, 10(2), 179-196.

Bennett, M. J. (1998). Intercultural communication: A current perspective. In M. J. Bennett (Ed.), Basic concepts of intercultural communication: Selected readings (s. 1-34). Boston: Intercultural Press.

Bennett, J. M., Bennett, M. J., \& Allen, W. (2003). Developing intercultural competence in the language classroom. In D. L. Lange \& R. M. Paige (Eds.), Culture as the core: Perspectives on culture in second language learning (s. 237-270). Greenwich: Information Age Publishing.

Bočánková, M. (2006). Interkulturní výzkumy na katedře anglického jazyka. Acta Oeconomica Pragensia, 14(4), 9-17.

Brebera, P., \& Kostková, K. (2008). K možnostem zkoumání profesní kompetence učitele cizích jazyků v některých jejích doménách. In T. Janík (Ed.), Metodologické problémy výzkumu didaktických znalostí obsahu (s. 51-64). Brno: Paido.

Byram, M. (1997). Teaching and assessing intercultural communicative competence. Clevedon: Multilingual Matters.

Byram, M., \& Morgan, C. (1994). Teaching-and-learning language-and-culture. Clevedon: Multilingual Matters.

Canale, M., \& Swain, M. (1980). Theoretical bases of communicative approaches to second language teaching and testing. Applied Linguistics, 1(1), 1-47.

Carroll, J. B. (1963). A model of school learning. Teachers' College Record, 64(8), 723-733.

Doyle, W. (1983). Academic work. Review of Educational Research, 53(2), 159-199.

Dunnett, S. C., Dubin, F., \& Lezberg, A. (1986). English language teaching from an intercultural perspective. In J. M. Valdes (Ed.), Culture bound: Bridging the cultural gap in language teaching (s. 148-161). Cambridge: Cambridge University Press.

Faltýn, J. (2005). Teoretická východiska multikulturní andragogiky. Praha: MJF Praha.

Fantini, A. E. (2006). Exploring and assessing intercultural competence. [Závěrečná zpráva výzkumného projektu]. Dostupné z http://www.experiment.org/documents/FinalGSI ResearchReport12.06.pdf

Göbel, K. (2007). Qualität im interkulturellen Englischunterricht. Eine Videostudie. Münster: Waxmann Verlag.

Guilherme, M. (2002). Critical citizens for an intercultural world. Foreign language education as cultural politics. Clevedon: Multilingual Matters.

Hammer, M. R. (2009). The intercultural development inventory: An approach for assessing and building intercultural competence. In M. A. Moodian (Ed.), Contemporary leadership and intercultural competence: Exploring the cross-cultural dynamics within organizations (s. 203-108). Thousand Oaks: Sage.

Harbord, J. (1992). The use of the mother tongue in the classroom. ELT Journal, 46(4), 350-355.

Hiebert, J., \& Wearne, D. (1993). Instructional tasks, classroom discourse, and students'learning in second-grade arithmetic. American Educational Research Journal, 30(2), 393-425.

Hinkel, E. (2006). Current perspectives on teaching the four skills. TESOL Quarterly, 40(1), 109-131. 
Hladík, J. (2010). Výzkum vztahu kognitivní a afektivní dimenze multikulturních kompetencí. In Český pedagogický výzkum v mezinárodním kontextu. Sborník př́spěvků XVII. ročníku celostátní konference ČAPV (s. 355-361). Ostrava: Pedagogická fakulta Ostravské univerzity. [CD-ROM]

Hofstede, G., \& Hofstede, G. J. (2005). Cultures and organizations: Software of the mind. London: McGraw-Hill.

Hrdlička, M. (2005). K otázce komunikační metody a komunikativnosti. Dostupné z http://www. auccj.cz/starestranky/kotazcekomunikac.htm

Huntington, S. P. (1996). The clash of civilizations and the remaking of world order. Penguin Books India.

Janík, T., \& Miková, M. (2006). Videostudie: výzkum výuky založený na analýze videozáznamu. Brno: Paido.

Kelly, M., Grenfell, M., Gallagher-Brett, A., Jones, D., Richard, L., \& Hilmarsson-Dunn, A. (2002). The training of teachers of a foreign language: Developments in Europe. A report to the European Commision Directorate General for Education and Culture. Dostupné z http:// ec.europa.eu/education/languages/pdf/doc493_en.pdf

Kostková, K. (2010a). Teacher and intercultural communicative competence as a challenge. In T. Janík, \& P. Knecht (Eds.), New pathways in the professional development of teachers (s. 232-240). Wien, Münster: LIT Verlag.

Kostková, K. (2010b). Intercultural communicative competence - its development and assessment. In Challenges in foreign language education (s. 59-65). Bratislava: Z-F Lingua.

Kostková, K. (2012). Rozvoj interkulturní komunikační kompetence. Brno: Masarykova univerzita.

Kubeš, M., Kurnický, R., \& Spillerová, D. (2004). Manažerské kompetence: Způsobilosti výjimečných manažerü. Praha: Grada.

Kumaravadivelu, B. (2001). Beyond methods: Macro-strategies for language teaching. New Haven: Yale University Press.

Lázár, I. (Ed.). (2003). Incorporating intercultural communicative competence in language teacher education. European Centre for Modern Languages: Council of Europe Publishing. Dostupné z http://www.ecml.at/documents/pub123bE2003_Lazar.pdf

Maňák, J. (2007). Kompetence ve struktuře kurikula. In D. Greger \& V. Ježková (Eds.), Školní vzdělávání: zahraniční trendy a inspirace (s. 87-101). Praha: Karolinum.

McDonnell, L. M. (1995). Opportunity to learn as a research concept and a policy instrument. Educational Evaluation and Policy Analysis, 17(3), 305-322.

Met, M. (1993). Teaching language and culture: A view from the schools. In J. E. Alatis (Ed.), Language, communication and social meaning (s. 259-274). Washington: Georgetown University Press.

Najvar, P., Najvarová, V., Janík, T., \& Šebestová, S. (2011). Videostudie v pedagogickém výzkumu. Brno: Paido.

Najvar, P., Najvarová, V., Soběslavská, V., Šebestová, S., Vlčková, K., \& Zerzová, J. (2008). CPV videostudie anglického jazyka: sběr dat a zamýšlené analýzy. Orbis scholae, 2(1), 73-91.

Navrátil, P. (2002). Výzkum interetnických vztahů. Brno: Phare.

Pešková, K. (2012). Vizuální prostředky pro výuku reálií v učebnicích němčiny. Brno: Masarykova univerzita.

Píšová, M. (2005). Klinický rok: procesy profesního rozvoje studentů učitelství a jejich podpora. Pardubice: Univerzita Pardubice, Fakulta humanitních studií. 
Průcha, J. (2001). Multikulturní výchova. Teorie - praxe - výzkum. Praha: ISV.

Průcha, J. (2006). Multikulturní výchova: př́ručka (nejen) pro učitele. Praha: Triton.

Rimmele, R. (2002). Videograph. Multimedia-Player zur Kodierung von Videos. Kiel: IPN.

Savignon, S. J. (1983). Communicative competence: Theory and classroom practice; texts and contexts in second language learning. Reading: Addison-Wesley.

Seidel, T., Prenzel, M., Duit, R., \& Lehrke, M. (Eds.). (2003). Technischer Bericht zur Videostudie „Lehr-Lern-Prozesse im Physikunterricht". Kiel: IPN.

Selinker, L., \& Tomlin, R. S. (1986). An empirical look at the integration and separation of skills in ELT. ELT Journal, 40(3), 227-235.

Sercu, L. (2002a). Autonomous learning and the acquisition of intercultural communicative competence: Some implications for course development. Language, Culture and Curriculum, 15(1), 61-74.

Sercu, L. (2002b). Implementing intercultural foreign language education. Belgian, Danish and British teachers' professional self-concepts and teaching practices compared. Language Awareness, 16(3), 150-165.

Skalková, J. (2007). Obecná didaktika. Praha: Grada.

Sockett, H. P., \& LePage, P. (2002). The missing language of the classroom. Teaching and Teacher Education, 18(2), 159-171.

Souhrnné poznatky o podpoře a rozvoji výuky cizích jazyků v předškolním, základním a středním vzdělávání v období let 2006-2009. (2010). Praha: Česká školní inspekce. Dostupné z http:// www.csicr.cz/cz/85027-podpora-a-rozvoj-vyuky-cizich-jazyku

Stern, H. H. (1992). Issues and options in language teaching. Oxford: Oxford University Press.

Swan, M. (1990). A critical look at the communicative approach. In R. Rossner \& R. Bolitho (Eds.), Currents of change in English language teaching (s. 73-98). Oxford: Oxford University Press.

Šebestová, S. (2011). Příležitosti $k$ rozvíjení řečových dovedností ve výuce anglického jazyka: videostudie. Brno: Masarykova univerzita.

Šebestová, S., Najvar, P., \& Janík, T. (2011). Příležitosti k rozvíjení řečových dovedností ve výuce anglického jazyka: samostatně anebo v integraci? Pedagogická orientace, 21(3), 322-357.

Tomalin, B., \& Stempleski, S. (1993). Cultural awareness. Oxford: Oxford University Press.

Triandis, H. C. (1989). Intercultural education and training. In P. Funke (Ed.), Understanding the USA: A cross-cultural perspective (s. 305-322). Tübingen: Narr Verlag.

Usó-Juan, E., \& Martínez-Flor, A. (Eds.). (2006). Current trends in the development and teaching of the four language skills. Berlin: Mouton de Gruyter.

Zerzová, J. (2012). Interkulturní komunikační kompetence a její rozvíjení v hodinách anglického jazyka na 2. stupni ZŠ. Brno: Masarykova univerzita.

\section{Autorky}

Mgr. Jana Zerzová, M.A., Ph.D., Masarykova univerzita, Pedagogická fakulta, Katedra anglického jazyka a literatury, Poříćí 9/11, 60300 Brno, e-mail: janazerzovacz@yahoo.com

Mgr. Simona Šebestová, Ph.D., Masarykova univerzita, Pedagogická fakulta, Institut výzkumu školního vzdělávání, Poříčí 31, 60300 Brno, e-mail: ssimkka@gmail.com 


\title{
Opportunities to develop intercultural communicative competence in the context of language skills: IRSE Video Study of English
}

\begin{abstract}
The empirical study deals with the topic of teaching intercultural communicative competence (ICC) and its integration with the development of language skills in Czech lower-secondary English classes. The aim of the study is to investigate which language skills pupils use when developing their ICC and what their proportion is. The introductory part and the second part of the study introducing its theoretical background and terminology is followed by methodological part (chapter 3 ) describing the sample (79 English lessons of 25 teachers videotaped in the $7^{\text {th }}$ and $8^{\text {th }}$ grades of Czech lower-secondary classes in three regions within the IRSE Video Study of English project), the way of processing the data (recording, transcription, coding), the research questions and two systems of categories (a system for analyzing teaching ICC and language skills), that were used for analyses of the videotaped lessons. The findings show that developing the ICC may be characterized by employing receptive skills, whereas the occurrence of productive skills seems rather low. The development of the ICC in English lessons is limited to focusing on the cognitive level with almost no attention paid to the behavioral and affective aspects.
\end{abstract}

Keywords: communicative competence, English teaching, foreign language teaching, ICC, intercultural competence, intercultural communicative competence, language skills, opportunities to learn, system of categories, teaching and learning, video study

Klusák, M. (2014). Morální vývoj školáků a předškoláků: paradigmatické výzvy dle Jeana Piageta. Praha: Karolinum.

Monografie Morální vývoj školáků a předškoláků. Paradigmatické výzvy dle Jeana Piageta představuje podrobnou analýzu výzkumu Jeana Piageta v oblasti morálního vývoje dítěte. Text je členěn do dvou oddílů. Ve své první, interpretační části nabízí náhled do Piagetovy teorie morálního vývoje dítěte s dưrazem na morální výzvy, které dítě během svého vývoje přijímá a které jej „posouvají“ od egocentrické heteronomie k decentrované autonomii. Druhá, faktografická část zprostředkovává zakotvení Piagetovy teorie v empirii. Čtenáři jsou zde nabízeny k vlastní interpretaci všechny výzkumné situace, ze kterých Piagetova teorie vychází. Vývojové výzvy plynoucí z těchto situací kniha sdružuje do tří oborů uplatnění dětského morálního hodnocení: konflikty s autoritou, problematika trestání a instituce her organizovaných jako soutěž. Autor rovněž analyzuje účast dětí na tomto typu her a skutečnost, proč Piaget považoval právě tyto hry za nejvíce inspirativní pro vývoj dětského morálního hodnocení a jak toto hraní zkoumal. 